\title{
Evaluation of maternal serum levels of cell adhesion molecules and endothelial inflammatory markers in normal pregnancy, gestational hypertension and pre-eclampsia
}

\author{
Taru Gupta, Sarika Arora, Anil Kumar, Nupur Gupta*, Sangeeta Gupta
}

Department of Obstetrics and Gynecology and Biochemistry, ESI PGIMSR Basaidarapur New Delhi, India

Received: 19 April 2017

Accepted: 01 May 2017

*Correspondence:

Dr. Nupur Gupta,

E-mail: drnupurgupta@gmail.com

Copyright: $($ ) the author(s), publisher and licensee Medip Academy. This is an open-access article distributed under the terms of the Creative Commons Attribution Non-Commercial License, which permits unrestricted non-commercial use, distribution, and reproduction in any medium, provided the original work is properly cited.

\begin{abstract}
Background: Hypertensive disorders complicate 5 to $10 \%$ of all pregnancies. Despite the still unexplained pathogenesis, endothelial dysfunctions and inflammatory mediators are thought to be responsible for the pathogenesis gestational hypertension and pre-eclampsia. Aims and objective of the study was to determine the serum levels of cell adhesions molecules - VCAM-1 and ICAM-1 and endothelial inflammatory markers TNF- $\alpha$ and homocysteine in normal pregnancies, Gestational Hypertension and in Pre-eclampsia

Methods: The cross-sectional study was carried out in Department of Obstetrics and Gynecology and Biochemistry, ESI-PGIMSR, New Delhi between October 2013-April 2015. 150 patients who gave informed written consent were enrolled and were divided equally in three groups of 50 each (normotensive, gestational hypertensive and preeclamptic patients). Three groups have been compared in terms of variables such as age, BMI, gestational age, systolic and diastolic blood pressure, platelet count, AST, ALT, mode of delivery, neonatal weight, VCAM-I, ICAMI, homocysteine and TNF-alpha concentrations.

Results: We found the higher concentrations of vascular cell adhesions molecules (VCAM-1 and ICAM-1) and inflammatory mediators (homocysteine and TNF $\alpha$ ) in gestational hypertensive patients and in pre-eclamptic patients. Out of four markers, concentrations of ICAM-1 was found in largest proportions and it was also statistical significant. $\mathrm{P}$ value was $<0.001$. Though in our study concentration VCAM-1, homocysteine and TNF- $\alpha$ were also high in gestational hypertensive groups as compared with normotensive patients, but they were not statistical significant.

Conclusions: We conclude that higher concentrations of vascular cell adhesions molecules and inflammatory mediators may be responsible for hypertensive disorders of pregnancy suggesting the role of endothelial dysfunction as a central pathogenic feature in development of preeclampsia.
\end{abstract}

Keywords: Gestational hypertension, Inflammatory mediators (homocysteine and TNF $\alpha$ ), Pre-eclampsia, Vascular cell adhesions molecules

\section{INTRODUCTION}

Preeclampsia is a pregnancy specific disorder clinically characterized by hypertension, proteinuria or presence of multiorgan dysfunction. There is a growing body of evidence to indicate that endothelial dysfunction has a crucial role in the pathogenesis of pre-eclampsia.
Members of the immunoglobulin superfamily of endothelial adhesion molecules, (vascular cell adhesion molecule (VCAM-1) and intercellular cell adhesion molecule (ICAM-1)) and endothelial inflammatory markers (homocysteine and TNF- $\alpha$ ) participate in leukocyte adhesion to the endothelium and may play an important role in pathogenesis of Preeclampsia. For the 
most part, it is unclear whether these substances contribute to endothelial dysfunction or whether their dysregulation is a marker of endothelial injury.

VCAM-1 is a member of the immunoglobulin super family. It has a single chain glycoprotein structure and functions as a transmembrane receptor in vascular endothelial cell membrane. This gene encodes a cell surface sialoglycoprotein expressed by cytokine-activated endothelium. This type I membrane protein mediates leukocyte-endothelial cell adhesion and signal transduction, and may play a role in the development of artherosclerosis and rheumatoid arthritis. It is located on chromosome 1. VCAM-1 is present on a number of activated cells, including activated endothelial cells. Increased concentrations of VCAM-1 reflect increased expression of this molecule on the endothelial surface. ${ }^{1,2}$

ICAM-1 is a member of the immunoglobulin super family located on chromosome 19, mediates its functional activity through binding to leukocyte $\beta 2$ - integrins. The ICAM-1 molecule is functionally involved in the regulation of adhesion of leukocytes to the endothelium as well as in leukocyte migration. This gene encodes a cell surface glycoprotein which is typically expressed on endothelial cells and cells of the immune system. ${ }^{2}$

Homocysteine is a sulphur containing compound that is derived from demethylation of the dietary essential amino acid methionine to produce compounds required for the growth of cells and tissues in the human body. Hyperhomocysteinemia is an independent risk factor for cardiovascular diseases and common obstetric problems. It interferes with fibrinolytic system and undergoes autooxidation to produce reactive oxygen species (ROS), which inactivates nitric oxide and thromomodulin leading to endothelial dysfuntion which is associated with number of pregnancy associated diseases such as gestational hypertension and pre-eclampsia. TNF- $\alpha$ is a multifunctional pro-inflammatory cytokine that belongs to the tumor necrosis zactor (TNF) super family. This cytokine is mainly secreted by macrophages.

This cytokine is involved in the regulation of a wide spectrum of biological processes including cell proliferation, differentiation, apoptosis, lipid metabolism, and coagulation. This proinflammatory cytokine can be a potential marker of the severity of the preeclamptic syndrome, without being an indicator of the fetal status at birth. ${ }^{3}$ Objectives of the study was to estimate the maternal serum levels of vascular cell adhesion molecules-1 (VCAM-1), intercellular adhesion molecules-1 (ICAM-1), endothelial inflammatory markers TNF- $\alpha$ and homocysteine in normal pregnancies, gestational hypertension and pre-eclampsia and to correlate them with clinical presentation, so that the association and co relation with the pathology can be understood and the knowledge so gained can be used for the prevention and prediction of pre-eclampsia.

\section{METHODS}

The study was conducted in Department of Obstetrics and Gynaecology and Biochemistry, ESIC-PGIMSR, Basaidarapur, New Delhi between October 2013 and April 2015. The study was approved by Institutional Ethical Committee. Sample size was 150 pregnant women [Control group of Normotensive women (50), Study group -1 Gestational Hypertensive women (50) and Study group-2 Pre-eclamptic women (50)].

Pregnant women meeting the following inclusion and exclusion criteria were selected after obtaining a written and informed consent. Inclusion criteria were primigravida with singleton pregnancy with 34 weeks to 40 weeks' period of gestation.

Exclusion criteria were pregnant women with multiple pregnancies, chronic hypertension, diabetes mellitus and heart disease, history of peripheral vascular diseases, deranged renal function, tuberculosis, sepsis, pancreatitis, rheumatoid arthritis and neoplasia, $\mathrm{BMI}<19$ and $\mathrm{BMI}>30$ $\mathrm{kg} / \mathrm{m} 2$, presence of any acute febrile illness.

Detailed history was taken and thorough clinical evaluation was done and relevant investigations were sent.

In all the groups, maternal blood was collected before delivery and assayed for Serum levels of VCAM-1, ICAM-1, TNF- $\alpha$, homocysteine.

$5 \mathrm{ml}$ peripheral venous blood sample was collected in SST II advanced gel separator vacuum evacuated collection tubes from BD. Blood so collected was allowed to clot for 15-20 minutes.

Samples were then centrifuged at $3500 \mathrm{rpm}$ for 10 minutes and the supernatant was analyzed for serum homocysteine immediately and rest of the serum was stored in three aliquots at -20 degree Celsius (one each for ICAM-1, VCAM-1 and TNF- $\alpha$ ) till batch analysis was carried out by ELISA. All measurements were performed by an investigator blinded to the study group assignments.

\section{Estimation of Serum Homocysteine}

Homocysteine (Hcy) is a thiol-containing amino acid produced by intracellular demethylation of methionine. Serum hcy was estimated by the enzymatic method, using Diazyme homocysteine enzymatic assay kit on fully automated Beckman AU 480 Bichemistry analyzer.

\section{Estimation of Serum ICAM-1}

Serum ICAM-1 was estimated by Diaclone human sICAM-1/CD54 solid-phase sandwich Enzyme Linked Immunosorbent Assay (ELISA) kit which ranged from 219 to $1042 \mathrm{ng} / \mathrm{ml}$ for normal human sera. 


\section{Estimation of Serum VCAM-1}

Serum VCAM-1 was estimated by Diaclone human sVCAM-1/CD106 solid-phase sandwich Enzyme Linked Immunosorbent Assay (ELISA) kit which ranged from 180 to $1502 \mathrm{ng} / \mathrm{ml}$ for normal human sera.

\section{Estimation of Serum TNF- $\alpha$}

Serum TNF- $\alpha$ was estimated by Diaclone human sTNF$\alpha /$ CD106 solid-phase sandwich Enzyme Linked Immunosorbent Assay (ELISA) kit.

\section{Statistical analysis}

Statistical evaluation was carried out using SPSS version 20.0. The results were expressed as mean \pm standard deviation. Unpaired t-test/ Mann-Whitney U- test was applied for determining the significance of difference between the cases and controls for different variables. $\mathrm{P}$ value $<0.05$ was considered significant and $<0.01$ was considered highly significant. Pearson product-moment correlation coefficient (r) was used to find out any significant correlation between clinical as well as measured biochemical profiles of the cases and the controls. Regression analysis was done to find out relation between two measured parameters.

\section{RESULTS}

Maximum number of patient were between age group of $20-25$ years in all three groups. There was slight increase in BMI of gestational hypertensive group (23.84 \pm 2.52$)$, pre-eclamptic group $(23.75 \pm 2.26)$ as compared with normotensive group (22.94 \pm 2.23$)$. Thus, high BMI may be a risk factor for preeclampsia. The mean gestational age in normotensive patients was $(37.48 \pm 1.74)$ in gestational group $(37.30 \pm 1.66)$ and in pre-eclamptic group was (36.22 \pm 1.47$)$. Incidence of caesarean sections was more in gestational hypertension women $(44 \%)$ and in pre-eclamptic women $(64 \%)$ as compared to normotensive patients $(10 \%)$. Thus there is increased risk of caesarean delivery in hypertensive disorders of pregnancy. There was slightly more incidence of low birth weight in gestational hypertensive group (30\%) and in pre-eclamptic group (36\%) as compared with control group $(22 \%)$. Thus, incidence of low birth weight was found to be more in babies born to pre-eclamptic mothers but it was not statistically significant. The mean of VCAM-1 levels in control group was (305.60 \pm 178.54$)$ while in gestational hypertension group was $329.84 \pm 197.68(\mathrm{p}=0.531)$ and in pre-eclamptic women was $328.61 \pm 180.40(\mathrm{p}=0.542)$. Thus, in present study there were increased levels of VCAM-1 in both study groups as compared with control group but the difference was not statistically significant. On correlating VCAM-1 concentrations and TNF $\alpha$ concentration in three groups there was positive correlation found in normotensive groups $(\mathrm{r}=0.322, \mathrm{p}=0.023 *)$. In gestational hypertension group and pre-eclampsia group, a non-significant negative correlation was observed. During regression analysis between blood pressure and VCAM-1 concentrations the regression equation was $\mathrm{SBP}=132.7+0.01400 \quad$ VCAM-1 and $\mathrm{DBP}=75.73+0.005565$ VCAM-1 in three study groups but it was not statistically significant.

Table 1: Comparison of clinical parameters in normotensive, gestational hypertensive and pre-eclamptic women.

\begin{tabular}{|c|c|c|c|c|}
\hline Parameters & $\begin{array}{l}\text { Normotensive } \\
\text { women }(\mathrm{n}=50)\end{array}$ & $\begin{array}{l}\text { Gestational } \\
\text { Hypertensive }(n=50)\end{array}$ & $\begin{array}{l}\text { Pre-eclamptic } \\
\text { women }(n=50)\end{array}$ & P value \\
\hline & A & $\mathrm{B}$ & $\mathrm{C}$ & $\mathrm{B} / \mathrm{C}$ \\
\hline Age (years) $($ Mean \pm SD) & $23.68 \pm 4.5$ & $25.52 \pm 4.16$ & $25.12 \pm 3.67$ & NS \\
\hline p-value* & & $\mathrm{P}=0.045^{*}$ & $\mathrm{P}=0.065$ & \\
\hline BMI $\left(\mathrm{kg} / \mathrm{m}^{2}\right)($ Mean \pm SD $)$ & $22.94 \pm 2.23$ & $23.84 \pm 2.52$ & $23.75 \pm 2.26$ & NS \\
\hline p-value* & & 0.041 & & \\
\hline Gestational age (weeks) Mean \pm SD & $37.48 \pm 1.74$ & $37.30 \pm 1.66$ & $36.22 \pm 1.47$ & NS \\
\hline p-value* & & 0.57 & $<0.001$ & \\
\hline Pedal oedema in \% & $6 \%$ & $12 \%$ & $24 \%$ & NS \\
\hline p-value* & & NS & NS & \\
\hline Systolic BP (mmHg) Mean \pm SD & $112.64 \pm 11.47$ & $147.68 \pm 7.09$ & $151.36 \pm 7.38$ & NS \\
\hline p-value* & & $<0.001$ & $<0.001$ & \\
\hline Diastolic BP $(\mathrm{mmHg})$ Mean \pm SD & $69.92 \pm 8.56$ & $88.02 \pm 8.88$ & $80.56 \pm 9.67$ & NS \\
\hline p-value* & & $<0.001$ & $<0.001$ & \\
\hline
\end{tabular}

p-value*-Comparison of respective groups with control group; $\mathrm{P}$ Value $(\mathrm{B} / \mathrm{C})=$ Comparison between gestational hypertensive and preeclamptic; *Statistically significant, p value $<0.05$, NS=Non-Significant.

The mean of ICAM-1 concentration in control group was (157.34 \pm 38.31$)$, in gestational hypertension group was $(597.56 \pm 343.16)(\mathrm{p}<0.001)$, in pre-eclampsia group, the mean ICAM-1 values were 811.46 \pm 217.95 ( $\mathrm{p}<0.001$ ). The difference in ICAM-1 values of gestational hypertension group and pre-eclampsia was also 
statistically significant ( $p<0.001)$. Soluble ICAM-1 concentrations and TNF $\alpha$ concentration showed a significant positive correlation $(r=0.273, p=<0.001)$ when correlation studies were carried in the entire 150 subjects taken together. On doing regression analysis between blood pressure and ICAM -1concentrations the regression equation was $\mathrm{SBP}=119.3+0.03436 \mathrm{ICAM}-1$ in pregnant women and $\mathrm{DBP}=71.47+0.01159$ ICAM-1 in pregnant women in three studies groups. It was statistically significant $(p=<0.001)$.

Table 2: Comparison of maternal and perinatal outcome parameters in normotensive, gestational hypertensive and pre-eclamptic women.

\begin{tabular}{|c|c|c|c|c|}
\hline Parameters & $\begin{array}{l}\text { Normotensive } \\
\text { women }(n=50)\end{array}$ & $\begin{array}{l}\text { Gestational } \\
\text { hypertensive }(n=50)\end{array}$ & $\begin{array}{l}\text { Pre-eclamptic } \\
\text { women }(\mathrm{n}=50)\end{array}$ & $P$ value \\
\hline & A & B & $\mathrm{C}$ & $\mathrm{B} / \mathrm{C}$ \\
\hline Mode of delivery $\%$ of caesarean section & $10 \%$ & $44 \%$ & $64 \%$ & NS \\
\hline p-value* & & NS & NS & \\
\hline Neonatal birth weight $(\mathrm{kg})(\mathrm{Mean} \pm \mathrm{SD})$ & $2.74 \pm 0.42$ & $2.6 \pm 0.475$ & $2.56 \pm 0.41$ & NS \\
\hline p-value* & & 0.36 & 0.057 & \\
\hline APGAR score at 1 min $($ Mean \pm SD) & $7.94 \pm 1.25$ & $7.56 \pm 1.81$ & $7.56 \pm 1.72$ & NS \\
\hline p-value* & & 0.204 & 0.242 & \\
\hline
\end{tabular}
eclamptic; $*$ Statistically significant, $\mathrm{p}$ value $<0.05$, NS=Non-Significant.

Table 3: Comparison of laboratory parameters between control group, gestational hypertensive group and in pre-eclamptic group.

\begin{tabular}{|c|c|c|c|c|}
\hline $\begin{array}{l}\text { Measured laboratory } \\
\text { parameters }\end{array}$ & $\begin{array}{l}\text { Normotensive } \\
\text { women }(\mathrm{n}=\mathbf{5 0})\end{array}$ & $\begin{array}{l}\text { Gestational } \\
\text { hypertensive }(n=50)\end{array}$ & $\begin{array}{l}\text { Pre-eclamptic } \\
\text { women }(n=50)\end{array}$ & P value \\
\hline & A & $\mathrm{B}$ & $\mathrm{C}$ & $\mathrm{B} / \mathrm{C}$ \\
\hline Platelet Count $(\mathrm{Lakh} / \mathrm{mm} 3)($ Mean \pm SD) & $2.82 \pm 2.41$ & $2.28 \pm 0.51$ & $2.0740 \pm 0.509$ & NS \\
\hline p-value* & & 0.133 & $0.035^{*}$ & \\
\hline AST (U/L) (Mean \pm SD) & $26.90 \pm 5.09$ & $36.88 \pm 13.79$ & $88.20 \pm 63.38$ & NS \\
\hline p-value* & & $<0.001^{*}$ & $<0.001 *$ & \\
\hline ALT (U/L) (Mean \pm SD) & $30.96 \pm 21.25$ & $31.78 \pm 21.64$ & $67.38 \pm 55.29$ & NS \\
\hline p-value* & & 0.86 & $<0.001 *$ & \\
\hline VCAM-1 (ng/ml) Mean \pm SD & $305.60 \pm 1785.04$ & $329.84 \pm 197.68$ & $328.61 \pm 180.4$ & 0.974 \\
\hline p-value* & & 0.531 & 0.542 & \\
\hline ICAM-I (ng/ml) Mean \pm SD & $157.34 \pm 38.31$ & $597.56 \pm 343.16$ & $811.46 \pm 217.95$ & $<0.001 *$ \\
\hline p-value* & & $<0.001 *$ & $<0.001 *$ & \\
\hline Homocysteine $\mathrm{mmol} / \mathrm{L}$ Mean \pm SD & $8.69 \pm 6.34$ & $11.48 \pm 6.65$ & $13.30 \pm 7.65$ & 0.268 \\
\hline p-value* & & $0.022 *$ & $<0.001 *$ & \\
\hline TNF-alpha (pg/ml) Mean \pm SD & $4.71 \pm 2.81$ & $13.21 \pm 9.0$ & $11.16 \pm 16.84$ & 0.455 \\
\hline p-value* & & $<0.001 *$ & $0.008 *$ & \\
\hline
\end{tabular}

p-value*-Comparison of respective groups with control group; $\mathrm{P}$ Value $(\mathrm{B} / \mathrm{C})=$ Comparison between gestational hypertensive and preeclamptic; *Statistically significant, $p$ value $<0.05$, NS=Non-Significant.

The mean value of homocysteine in control group was $8.64 \pm 6.34 \mathrm{mmol} / \mathrm{L}$, in gestational hypertension group was $11.48 \pm 6.65 \mathrm{mmol} / \mathrm{L} \quad(\mathrm{p}=0.022)$ and in pre-eclamptic group, it was $13.30 \pm 7.65 \mathrm{mmol} / \mathrm{L}$ (p <0.001). Thus, homocysteine levels increase in hypertensive disorders of pregnancy. On doing regression analysis between blood pressure and homocysteine concentrations the regression equation was $\mathrm{SBP}=132.5+0.4235 \mathrm{HCY}$ - in pregnant women and $\mathrm{DBP}=75.34+0.1956 \mathrm{HCY}$ - in pregnant women in three study groups and was statistically significant $(\mathrm{p}=<0.001)$. Homocysteine and TNF $\alpha$ showed positive correlation in normotensive group and gestational hypertensive group but it was not statistically significant. In pre-eclamptic group, serum Homocysteine and TNF- $\alpha$ levels showed a significant positive correlation $(p=0.032)$. The mean value of TNF- $\alpha$ in control group was $4.71 \pm 2.81$, in gestational hypertensive group, it was $13.21 \pm 9.0(\mathrm{p}<0.001)$, while mean value in pre-eclamptic group was $11.16 \pm 16.84(\mathrm{p}=0.008)$. But on comparing gestational hypertensive group and preeclamptic group, no significant difference was found ( $p$ value $=0.455$ ). TNF- $\alpha$ levels were raised in hypertensive disorders of pregnancy. 

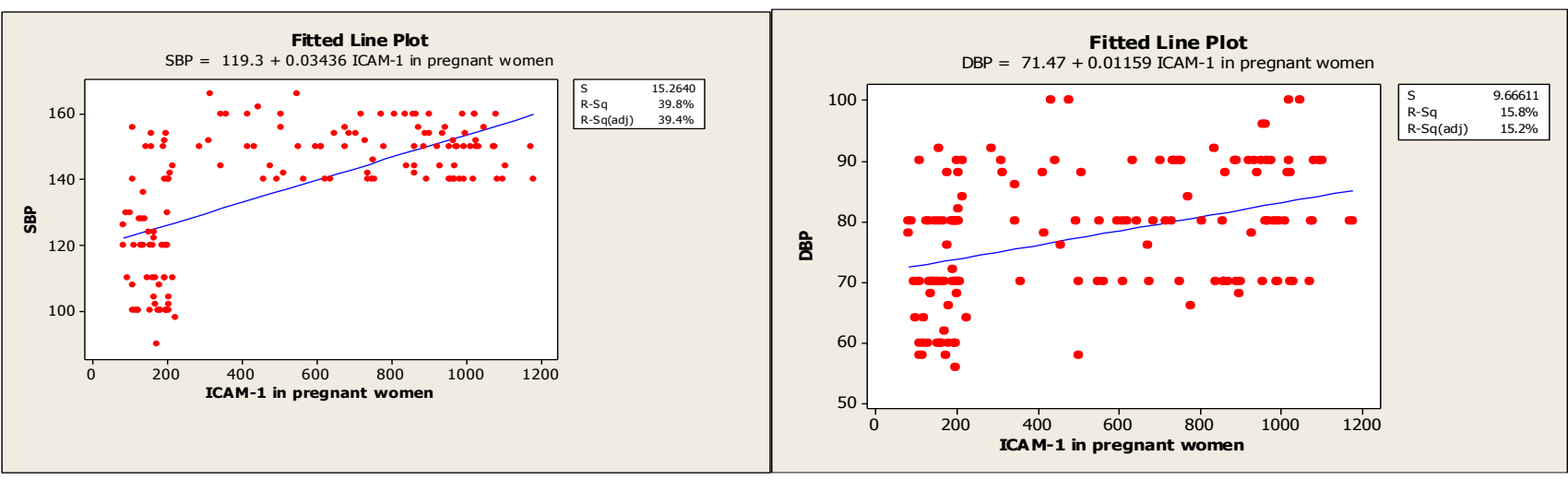

Figure 1: Fitted line regression plot between ICAM-1 values and SBP and DBP values in the study population.
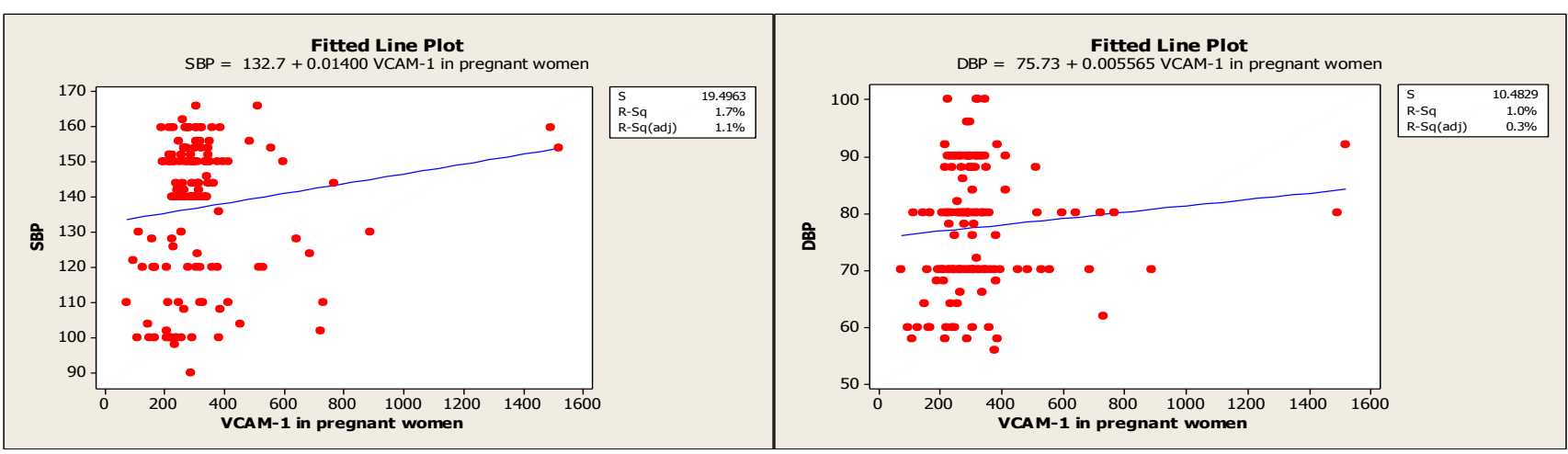

Figure 2: Fitted line regression plot between VCAM-1 values and SBP and DBP values in the study population.

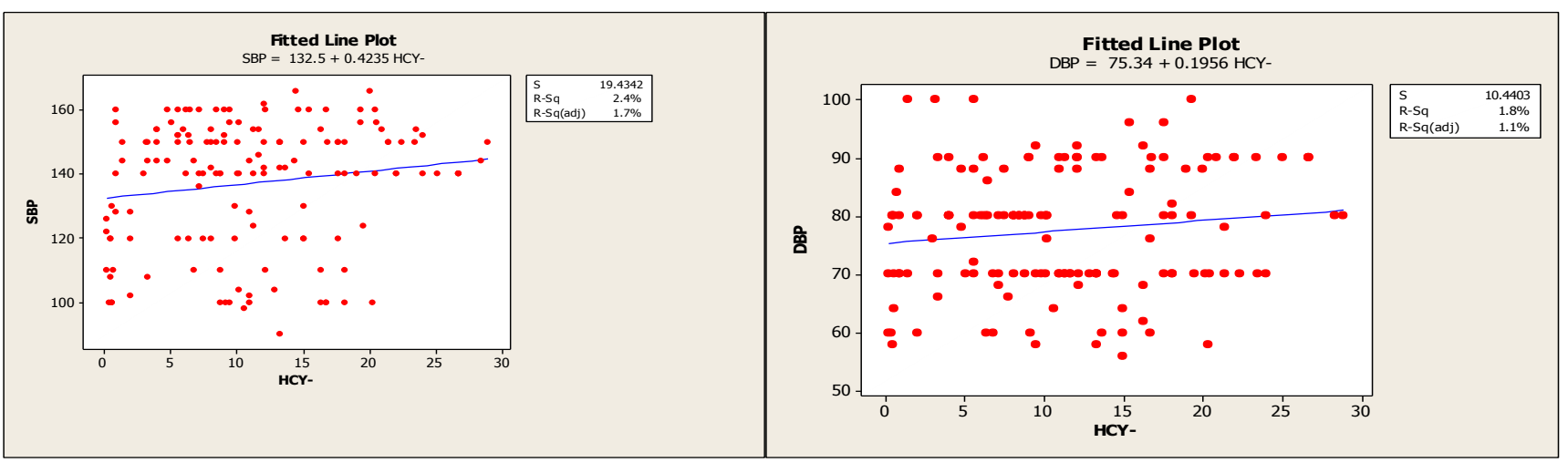

Figure 3: Fitted line regression plot between homocysteine values and SBP and DBP values in the study population.

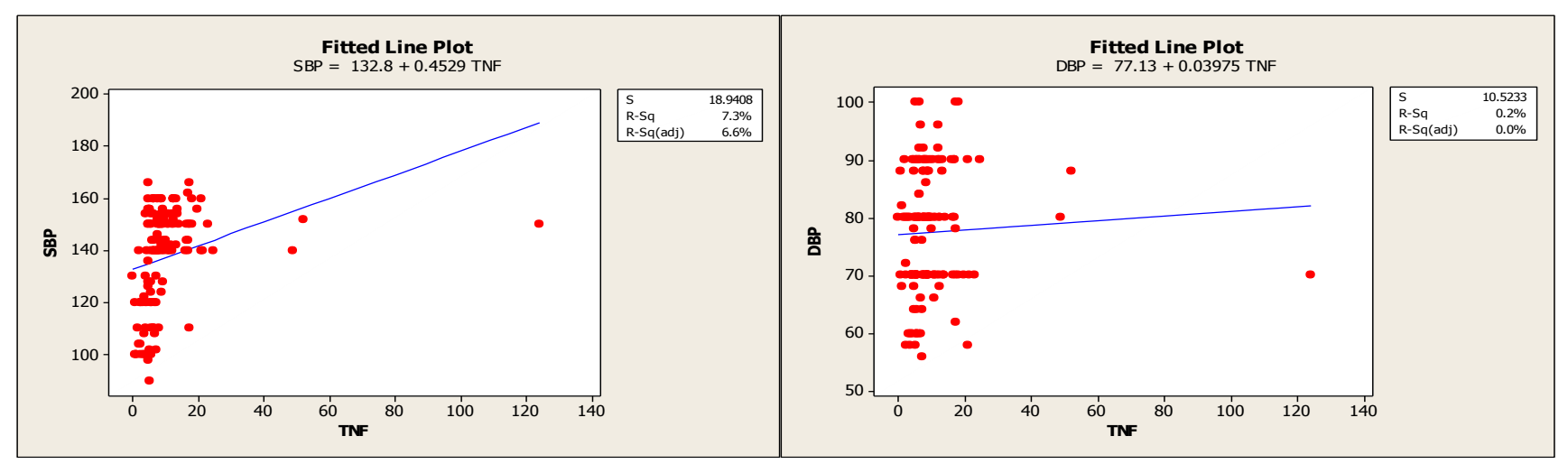

Figure 4: Fitted line regression plot between Serum TNF- $\alpha$ values and SBP and DBP values in the study population. 
TNF- $\alpha$ levels showed a significant positive correlation with Body Mass Index in normotensive patients $(r=0.287$, $\mathrm{p}=0.043$ ). The correlation was also found to be positive in gestational hypertensive patients but correlation was not significant $(\mathrm{r}=0.029, \mathrm{p}=0.840)$. In pre-eclamptic group a non-significant negative correlation was observed. TNF $\alpha$ levels showed a significant negative correlation with diastolic blood pressure in normotensive patients $(r=-$ 0.300 and $\mathrm{p}=0.034$ ). In gestational hypertensive group and in pre-eclamptic group, correlation was not significant. On doing regression analysis between blood pressure and TNF- $\alpha$ concentrations the regression equation was $\mathrm{SBP}=132.8+0.4529 \mathrm{TNF}$ in pregnant women and $\mathrm{DBP}=77.13+0.03975 \mathrm{TNF}$ in pregnant women in three study groups but it was statistically significant $(\mathrm{p}=<0.001)$ in systolic blood pressure but not in diastolic blood pressure.

\section{DISCUSSION}

Farzadina M et al conducted study which concluded that patients with severe preeclampsia had a significantly

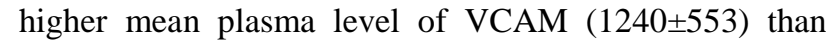
normal pregnant and mild pre-eclamptic women ( $\mathrm{P}$ $<0.05){ }^{4}$

Farzadina $\mathrm{M}$ et al conducted a cross-sectional study to determine the plasma concentrations of sVCAM-1, ICAM-1 and hs-CRP in peripheral blood obtained from normal pregnant women $(n=40)$, mild pre-eclampsia $(n=37)$ and severe pre-eclampsia $(n=38) .{ }^{5}$ There were significant difference in the means serum hs-CRP between normal pregnant women and mild pre-eclamptic women $(\mathrm{P}<0.05)$. Serum concentration of hs-CRP, sVCAM-1 (ng.ml) and sICAM-1 (ng.ml) were significantly higher in severe pre-eclampsia $(\mathrm{P}<0.05)$ than normal pregnancy. There were also significant differences in hs-CRP, sICAM- 1 and in sVCAM- 1 levels between mild and severe pre-eclampsia $(\mathrm{P}<0.05)$. There was no difference in the mean plasma log SVCAM1, sICAM-1 between normal pregnant women and mild pre-eclamptic women.

Study by Patel AP et al demonstrates an increase in the homocysteine levels in patients with preeclampsia than controls and levels of vitamin B12 and folic acid were found in normal limits but in the lower range in all groups. ${ }^{6}$

In a similar study done by Khosrowbeygi $\mathrm{A}$ and Ahmadvand $\mathrm{H}$ and Laskowska $\mathrm{M}$ et al maternal serum levels of total homocysteine were significantly higher in preeclamptic than in normal pregnant women. ${ }^{7,8}$

Some studies suggested that infection and inflammatory processes are related to preeclampsia. The role of inflammation and infection in the pathogenesis of preeclampsia is significant in developing countries, where the high incidence of chronic subclinical infection may contribute to the high incidence of preeclampsia.
In a study performed in 2008 increased expression of TNF- $\alpha$ mRNA in the placenta of preeclampsia has been reported. ${ }^{9}$ Their findings were consistent with those of present study. In a study by Sharma and coworkers performed on 104 cases of pre-eclampsia, normal pregnancy and non-pregnant women, the levels of TNF$\alpha$ were increased significantly in pre-eclampsia in comparison with the healthy pregnant and non-pregnant groups. ${ }^{10}$

Roudsari FV et al conducted a study on 37 women with preeclampsia (17 mild and 20 severe preeclampsia) and 41 normotensive pregnant women with similar gestational age at third trimester of pregnancy. ${ }^{11}$ All the preeclamptic cases had blood pressure $\geq 140 / 90 \mathrm{mmHg}$, and proteinuria $\geq 300 \mathrm{mg}$ in a 24 -h urine sample. Maternal serum TNF- $\alpha$ concentration was compared in all of them. The level of $\mathrm{TNF}-\alpha$ concentration was not statistically different between the studied groups. No significant correlation was found between preeclampsia and control group as they were compared in the view of maternal serum TNF- $\alpha$ concentration. These findings suggest that serum TNF- $\alpha$ is not significantly associated with preeclampsia.

\section{CONCLUSION}

The use of cytokines to predict preeclampsia is still controversial. These findings and previous studies demonstrated that TNF- $\alpha$ may be involved in the pathogenesis of PE and may identify the patients who are at high risk of PE. However, for close information, further studies in a large volume from different population are required. Higher concentrations of vascular cell adhesions molecules and inflammatory mediators may be responsible for hypertensive disorders of pregnancy because endothelial dysfunction is thought to be a central pathogenic feature in development of preeclampsia. In future, these soluble serum markers may be used as diagnostic markers for hypertensive disorders of pregnancy and to assess the severity and prognosis of disease.

\section{ACKNOWLEDGMENTS}

The authors would wish to express sincere gratitude to the participants in the study done at ESI PGIMSR Basaidarapur, New Delhi for their cooperation.

Funding: No funding sources Conflict of interest: None declared

Ethical approval: The study was approved by the Institutional Ethics Committee

\section{REFERENCES}

1. Fotis L, Agrogiannis G, Vlachos IS, Pantopoulou A, Margoni A, Kostaki M et al. Intercellular adhesion molecule (ICAM)-1 and vascular cell adhesion molecule (VCAM)-1 at the early stages of 
atherosclerosis in a rat model. In Vivo. 2012;26(2):243-50.

2. Guerraty MA, Grant GR, Karanian JW, Chiesa OA, Pritchard WF, Davies PF. Side-specific expression of activated leukocyte adhesion molecule (ALCAM; CD166) in pathosusceptible regions of swine aortic valve endothelium. J Heart Valve Dis. 2011;20(2):165-7.

3. Costin N, Blaga LD, Ciuchină S, Pop RB. Implication of tumor necrosis factor-alpha in preeclampsia. Appl Med Inform. 2008;23(3, 4):11-8.

4. Farzadnia M, Ayatollahi H, Sadeghian MH, Meybodi NT. Serum Level of Vascular Cell Adhesion Molecule-1 (sVCAM-1) in Sera. Acta Medica Iranica. 2009;47(1):65-70.

5. Farzadnia M, Ayatollahi H, Hasan-zade M, Rahimi HR. A comparative study of serum level of vascular cell adhesion molecule-1 (sVCAM-1), intercellular adhesion molecule-1 (ICAM-1) and high sensitive Creactive protein (hs-CRP) in normal and preeclamptic pregnancies. Iran $\mathrm{J}$ Basic Med Sci. 2013;16(5):689-93.

6. Patel AP, Chakrabarti C, Singh A, Patel JD, Mewada HA, Sharma SL. Effect of homocysteine, vitamin b12, folic acid during pregnancy. NHL J Med Sci. 2012;1:27-31

7. Khosrowbeygi A, Ahmadvand H. Circulating levels of homocysteine in preeclamptic women. Bangladesh Med Res Counc Bull. 2011;37:106-9.

8. Laskowska M, Oleszczuk J. Homocysteine in pregnancies complicated by preeclampsia with and without IUGR: a comparison with normotensive pregnant women with isolated IUGR and healthy pregnant women. Open J Obstet Gynecol. 2011;1:191-6.

9. Marusic J, Prusac IK, Tomas SZ, Karara JR, Roje D. Expression of inflammatory cytokines in placentas from pregnancies complicated with preeclampsia and HELLP syndrome. J Maternal-Fetal Neonat Med. 2013;26(7).

10. Sharma A, Satyam A, Sharma JB. Leptin, IL-10 and inflammatory markers (TNF-alpha, IL-6 and IL-8) in pre-eclamptic, normotensive pregnant and healthy non-pregnant women. Am J Reprod Immunol. 2007;58(1):21-30.

11. Vahid Roudsari F, Ayati S, Ayatollahi H, Esmaeily $\mathrm{H}$, Hasanzadeh M, Shahabian M et al. Comparison of maternal serum tumor necrosis factor-alpha(TNF- $\alpha$ ) in severe and mild preeclampsia versus normal pregnancy. Iranian $\mathrm{J}$ Reprod Bio Medicine. 2009;7(4):153-6.

Cite this article as: Gupta T, Arora S, Kumar A, Gupta N, Gupta S. Evaluation of maternal serum levels of cell adhesion molecules and endothelial inflammatory markers in normal pregnancy, gestational hypertension and pre-eclampsia. Int $\mathbf{J}$ Reprod Contracept Obstet Gynecol 2017;6: 2231-7. 